\title{
Diversity of monogenean parasites on gills of fishes from the Matapi River, in the Brazilian Amazon
}

\author{
Diversidade de parasitos monogeneas nas brânquias de peixes do Rio Matapi, \\ na Amazônia brasileira
}

\author{
Lígia Rigôr Neves ${ }^{1}$; ; Luciano Pereira Negreiros ${ }^{1,2}$ (D); Luís Maurício Abdon Silva ${ }^{3}$ (D); Marcos Tavares-Dias ${ }^{1,4 \star}$ (D) \\ ${ }^{1}$ Programa de Pós-graduação em Biodiversidade e Biotecnologia da Rede Bionorte, Universidade Federal do Amapá - UNIFAP, Macapá, \\ AP, Brasil \\ ${ }^{2}$ Instituto Federal do Acre - IFAC, Rio Branco, AC, Brasil \\ ${ }^{3}$ Núcleo de Pesquisas Aquáticas - NUPAq, Instituto de Pesquisas Científicas e Tecnológicas do Estado do Amapá - IEPA, Macapá, AP, Brasil \\ ${ }^{4}$ Empresa Brasileira de Pesquisa Agropecuária - Embrapa Amapá, Macapá, AP, Brasil
}

How to cite: Neves LR, Negreiros LP, Silva LMA, Tavares-Dias M. Diversity of monogenean parasites on gills of fishes from the Matapi River, in the Brazilian Amazon. Braz J Vet Parasitol 2020; 29(4): e013520. https://doi.org/10.1590/S1984-29612020081

\begin{abstract}
This study investigated the fauna of monogeneans on gills of 13 fish species from the Matapi River, Brazilian Amazon. A total 548 fish belonging to 13 species (1 Anostomidae, 3 Characidae, 1 Curimatidae, 1 Hemiodontidae, 2 Serrasalmidae, 3 Scianidae, 1 Ageneiosidae and 1 Tetradontidae) were examined. From these fish, 6 species were infected and with a total prevalence of $22.4 \%$. Monogeneans collected are represented by the following taxa: Anacanthorus gravihamulatus, Notozothecium minor, Notozothecium penetrarum, Diplectanum piscinarius, Aetheolabes goeldiensis, Euryhaliotrema succedanus, Anacanthorus jegui, Urocleidoides astyanacis, Urocleidoides strombicirrus, Euryhaliotrema sp. and Urocleidoides spp. There was a variation in the prevalence, mean intensity and mean abundance of monogeneans among the host populations examined. Monogeneans of Metynnis lippincottianus, Plagioscion squamosissimus, Astyanax bimaculatus and Curimata incompta presented a highly aggregated dispersion pattern. Body weight of $M$. lippincottianus and $C$. incompta presented a weak positive correlation with abundance of parasites. Lastly, this is first study for 12 fish species from the Matapi River and the first report of E. succedanus for Plagioscion surinamensis and N. penetrarum for Serrasalmus rhombeus.
\end{abstract}

Keywords: Brazil, ectoparasites, freshwater fish, infection, Monogenea.

\section{Resumo}

Este estudo investigou a fauna de monogeneas das brânquias de 13 espécies de peixes do Rio Matapi, na Amazônia brasileira. Foram examinados um total de 548 peixes pertencentes a 13 espécies (1 Anostomidae, 3 Characidae, 1 Curimatidae, 1 Hemiodontidae, 2 Serrasalmidae, 3 Scianidae, 1 Ageneiosidae e 1 Tetradontidae). Entre esses peixes, 6 espécies estavam infectadas e houve uma prevalência total de 22,4\%. As espécies de monogeneas coletadas foram distribuídas nos seguintes táxons: Anacanthorus gravihamulatus, Notozothecium minor, Notozothecium penetrarum Diplectanum piscinarius, Euryhaliotrema sp., Aetheolabes goeldiensis, Euryhaliotrema succedanus, Anacanthorus jegui, Urocleidoides astyanacis, Urocleidoides strombicirrus Urocleidoides spp. Houve variação na prevalência, intensidade média e abundância média de monogeneas entre as populações hospedeiras. Monogeneas em Metynnis lippincottianus, Plagioscion squamosissimus, Astyanax bimaculatus e Curimata incompta apresentaram um padrão de dispersão altamente agregado. O peso corporal de $M$. lippincottianus do Rio Matapi mostrou uma correlação positiva fraca com a abundância de $A$. jegui. O comprimento de $C$. incompta também mostrou uma correlação positiva fraca com abundância de Urocleidoides spp. Por fim, este é primeiro estudo para 12 espécies de peixes da bacia do Rio Matapi e registra pela primeira vez E. succedanus para Plagioscion surinamensis e N. penetrarum para Serrasalmus rhombeus.

Palavras-chave: Brasil, ectoparasitos, peixes de água doce, infecção, Monogenea.

Received June 8, 2020. Accepted August 11, 2020.

*Corresponding author: Marcos Tavares-Dias. E-mail: marcos.tavares@embrapa.br 


\section{Introduction}

The Amazon River system has a high diversity and richness of fish species, representing the $7 \%$ of fish species form the planet. This richness and diversity are related to the various environmental characteristics of this basin, such as the seasonal variation in water level, $\mathrm{pH}$, temperature, transparency, aquatic productivity, complexity of biotopes (lakes, rivers and streams), habitats (aquatic macrophytes and flooded forest), as well as other aspects directly related to its geology (Leal et al., 2018). In addition, this large hydrographic basin is formed by several tributaries of different size and importance for fishing activities that generates food and income for many riverine populations, as for example the Matapi River basin (Silva et al., 2016; Sousa et al., 2019).

The Matapi River is born in the central region of the state of Amapá (Brazil), flowing into the Amazon River, near the municipality of Santana. Its main tributaries are the Flexal and Pirativa rivers, and the Maruanum and Lago streams. This basin is influenced by daily floods from the tides of the Amazon River and is therefore influenced by the discharges from the Amazon River. These tides considerably affect the hydrodynamics of inundated forest and floodplain areas in the Matapi River basin (Santos et al., 2004; Silva et al., 2016; Sousa et al., 2019) and consequently, the life history of 104 species of fish known for this basin, among Characiformes, Cichliformes, Siluriformes, Clupeiformes, Tetraodontiformes, Gymnotiformes and Beloniformes. Among these families, Serrasalmidae, Characidae and Cichlidae are the most predominant (Silva et al., 2016). Despite this diversity of the ichthyofauna, there are only reports of monogeneans in the following cichlids: Geophagus camopiensis (Pellegrin, 1903), Pterophyllum scalare (Schultze, 1823), Satanoperca jurupari (Heckel, 1840) and Satanoperca acuticeps (Heckel, 1840) (Ferreira-Sobrinho \& Tavares-Dias, 2016) and Hemibrycon surinamensis (Géry, 1962) (Sousa et al., 2019).

Monogenea (Van Beneden, 1858) are, in general, ectoparasites that mainly infect fish species, and have a simple and direct cycle and, consequently, may present a high reproduction rate in these hosts (Lapera et al., 2017). Some biotic factors influence the diversity and infection levels of monogeneans in fish, including the behavior, migratory habits, size, age, and sex of the hosts. Abiotic factors such as pollution, low dissolved oxygen, pH, water temperature and seasonality are also important for the levels of monogenean infection (Dogiel, 1961; Lizama et al., 2008; Vital et al., 2011, Takemoto et al., 2013; Tavares-Dias et al., 2014, 2017; Ferreira-Sobrinho \& Tavares-Dias, 2016). Therefore, the diversity and infection levels by monogeneans can vary between the different species of fish (Whittington \& Chisholm, 2008; Cohen et al., 2013), influenced by several factors. However, as the diversity of monogeneans in fish from the Matapi River is little known, the aim of this study was to investigate the fauna of these ectoparasites in the gills of 13 fish species of this basin.

\section{Material and Methods}

\section{Fish collection procedures}

Bimonthly, between March 2012 and August 2013, 13 species of fish were collected in the Matapi River (Table 1), in the municipality of Santana, state of Amapá, Brazil (Figure 1), for analysis of monogeneans in the gills. Fish were collected using gill nets of various mesh sizes $(20,25,30,35,40$ and $70 \mathrm{~mm}$ between knots), matapi traps, casting nets, hand lines and longlines, and the mean duration of fishing effort was $8 \mathrm{~h}$. Gills were collected and fixed in formalin (5\%) and transported to Laboratory of Aquaculture and Fishery of Embrapa Amapá, in Macapá (Brazil).

During fish collection, water temperature, electrical conductivity and $\mathrm{pH}$ were measured using a multiparameter analyzer (Horiba, model W23-XD). A Secchi disk was used to determine the transparency. The suspended solids analysis was performed using the gravimetric method and membrane filtration. Rainfall data were obtained from the Hydrometeorology and Renewable Energy Center (NHMET) of the Institute of Scientific and Technological Research of the State of Amapá (IEPA). The temperature was $27.5 \pm 1.5^{\circ} \mathrm{C}, \mathrm{pH} 5.5 \pm 0.7$, electrical conductivity $2.8 \pm 1.9 \mu \mathrm{S} / \mathrm{cm}$, suspended solids $25.0 \pm 29.5$, transparency $85.0 \pm 57.3 \mathrm{~cm}$ and rainfall $219.4 \pm 120.0 \mathrm{~mm}$. Maximum temperature and precipitation occurred of June to December and minimum temperature and precipitation occurred of January to May.

The present study was conducted in accordance with the recommendations of the Brazilian College for Animal Experimentation and with authorization from the Ethics Committee for Use of Animals of Embrapa Amapá (Protocol No 014 - CEUA/CPAFAP). 


\section{Parasite collection and analysis procedures}

Each fish was weighed $(\mathrm{g})$, measured for total length $(\mathrm{cm})$, and analyzed for the presence of monogeneans. The gills were removed and analyzed using a stereomicroscope. The monogeneans found were preserved in ethyl alcohol (70\%). The techniques used to count and prepare the parasites for identification were those previously recommended by Eiras et al. (2006). The ecological terms used were those recommended by Bush et al. (1997).

In order to detect the distribution pattern of the parasite infracommunities (Rózsa et al., 2000), the index of dispersion (ID) and the Poulin discrepancy index (D) were calculated using the Quantitative Parasitology 3.0 software for species with prevalence $>10 \%$. The ID significance for each infracommunity was tested using the $d$-statistic (Ludwig \& Reynolds, 1988).

Differences in parasite prevalence between host species were evaluated using the $\mathrm{G}$ test. The correlation between the parasite abundance with length and weight of hosts was estimated using the Spearman correlation coefficient (Zar, 2010).

Table 1. Body parameters of the host fish species collected in Matapi River, state of Amapá (Brazil).

\begin{tabular}{|c|c|c|c|}
\hline Order, Family, and fish species & $\mathbf{N}$ & Weight (g) & Length $(\mathrm{cm})$ \\
\hline \multicolumn{4}{|l|}{ CHARACIFORMES } \\
\hline \multicolumn{4}{|l|}{ Anostomidae } \\
\hline Leporinus friderici (Bloch, 1794) & 50 & $44.6 \pm 31.2$ & $14.0 \pm 3.8$ \\
\hline \multicolumn{4}{|l|}{ Characidae } \\
\hline Astyanax lacustris (Lütken, 1875) & 75 & $11.7 \pm 4.8$ & $8.2 \pm 0.9$ \\
\hline Moenkhausia lepidura (Kner, 1858) & 8 & $9.6 \pm 5.5$ & $9.5 \pm 1.5$ \\
\hline Tetragonopterus chalceus (Spix \& Agassiz, 1829) & 40 & $19.6 \pm 17.4$ & $9.3 \pm 2.1$ \\
\hline \multicolumn{4}{|l|}{ Curimatidae } \\
\hline Curimata incompta (Vari, 1984) & 132 & $33.7 \pm 17.9$ & $12.5 \pm 2.7$ \\
\hline \multicolumn{4}{|l|}{ Hemiodontidae } \\
\hline Hemiodus unimaculatus (Bloch, 1794) & 48 & $30.8 \pm 13.1$ & $12.4 \pm 3.2$ \\
\hline \multicolumn{4}{|l|}{ Serrasalmidae } \\
\hline Metynnis lippincottianus (Cope, 1870) & 89 & $11.1 \pm 6.8$ & $7.4 \pm 1.2$ \\
\hline Serrasalmus rhombeus (Linnaeus, 1766) & 9 & $17.7 \pm 20.5$ & $6.5 \pm 2.5$ \\
\hline \multicolumn{4}{|l|}{ PERCIFORMES } \\
\hline \multicolumn{4}{|l|}{ Sciaenidae } \\
\hline Plagioscion auratus (Castelnau, 1855) & 14 & $101.6 \pm 86.6$ & $19.9 \pm 5.5$ \\
\hline Plagioscion squamosissimus (Heckel, 1840) & 51 & $56.3 \pm 54.4$ & $15.7 \pm 5.7$ \\
\hline Plagioscion surinamensis (Bleeker, 1973) & 5 & $13.6 \pm 8.1$ & $8.9 \pm 3.1$ \\
\hline \multicolumn{4}{|l|}{ SILURIFORMES } \\
\hline \multicolumn{4}{|l|}{ Ageneiosidae } \\
\hline Ageneiosus ucayalensis (Castelnau, 1855) & 10 & $55.8 \pm 19.6$ & $19.8 \pm 4.5$ \\
\hline \multicolumn{4}{|l|}{ TETRAODONTIFORMES } \\
\hline \multicolumn{4}{|l|}{ Tetraodontidae } \\
\hline Colomesus asellus (Muller \& Troschel, 1849) & 17 & $17.7 \pm 9.1$ & $8.6 \pm 1.2$ \\
\hline Total & 548 & - & - \\
\hline
\end{tabular}




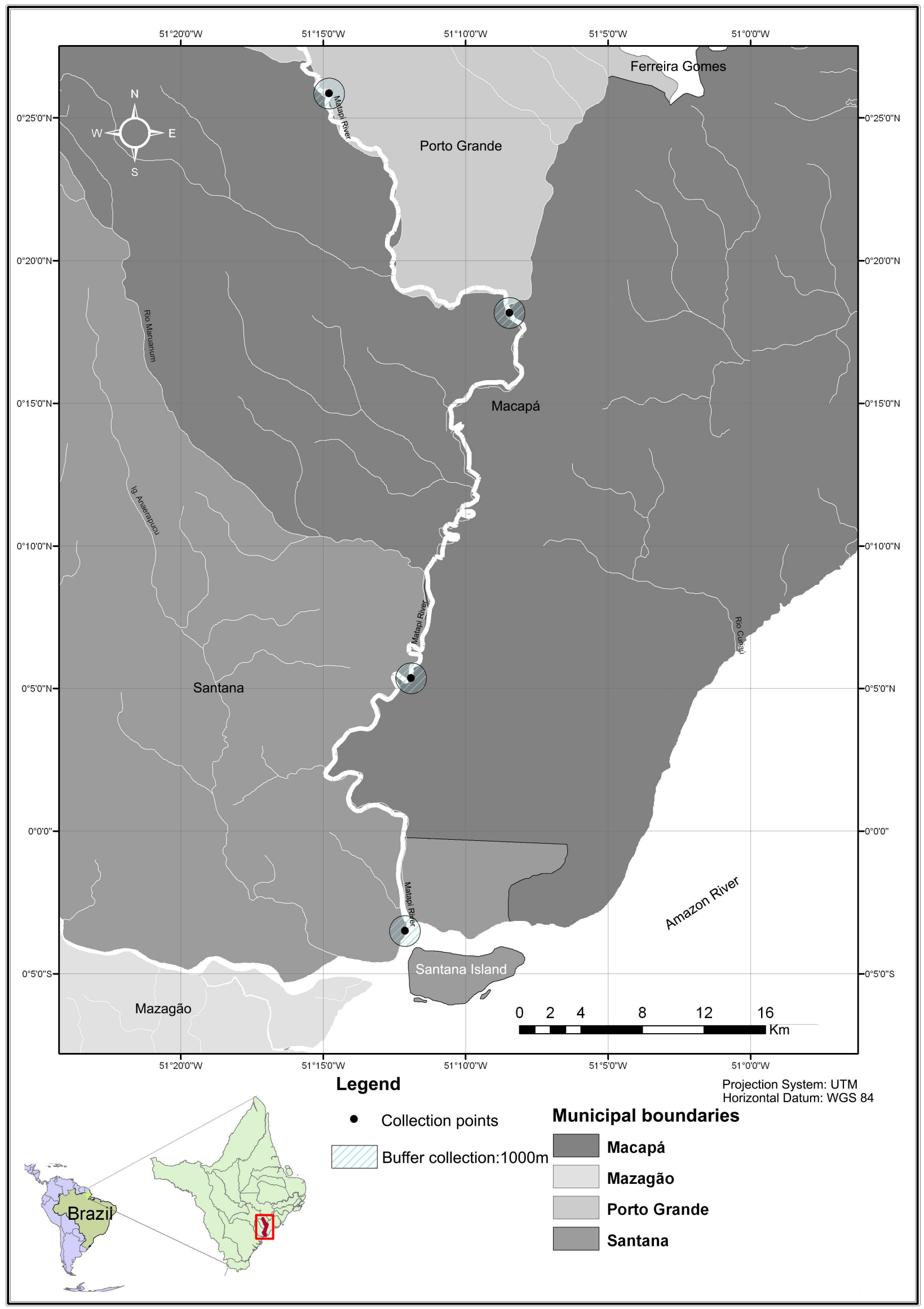

Figure 1. Collection sites of the fish species in Matapi River, state of Amapá, Brazil. 


\section{Results}

Thirteen fish species were caught and a total of 548 specimens were examined. The total prevalence of monogeneans was 22.4\%, and Metynnis lippiconttianus, Curimata incompta and Astyanax bimaculatus were the more abundant fish species (Table 1).

From the 13 species of fish examined, six species were infected by one or more species of monogeneans, such as: Anacanthorus gravihamulatus Van Every \& Kristsky, 1992; Notozothecium minor Boerger \& Kristsky, 1988; Notozothecium penetrarum Boerger \& Kristsky, 1988; Diplectanum piscinarius Kristsky \& Thatcher, 1984; Aetheolabes goeldiensis Boerger \& Kristsky, 2009; Euryhaliotrema succedanus Kristsky \& Boerger, 2002; Anacanthorus jegui Kristsky \& Boerge, 2002; Urocleidoides astyanacis Gioia, Cordeiro \& Artigas, 1988; Urocleidoides strombicirrus (Price \& Bussing, 1967) Kristsky \& Thatcher, 1974; Euryhaliotrema sp.; Urocleidoides sp.1 and Urocleidoides sp.2. There was a variation in the prevalence, mean intensity and mean abundance of monogeneans among the host populations examined (Table 2). The prevalence of monogeneans in Serrasalmus rhombeus was similar to Plagioscion squamosissimus $(G=0.951, p=0.548)$, Plagioscion surinamensis $(G=0.498, p=0.929)$, Metynnis lippincottianus $(G=0.098, p=0.890)$, Astyanax bimaculatus $(G=5.019, p=0.059)$ and Curimata incompta $(G=0.057, p=0.874)$. The prevalence of monogeneans in $P$. squamosissimus was similar to $P$. surinamensis $(G=0.001, p=0.651)$ and C. incompta $(G=3.107, p=0.113)$, and lower than in $M$. lippincottianus $(G=7.456, p=0.011)$ and A. bimaculatus $(G=5.992, p=0.024)$. The prevalence of monogeneans in $P$. surinamensis was similar to $M$. lippincottianus $(G=1.237, p=0.549)$ and $A$. bimaculatus $G=0.867, p=0.640)$ and $C$. incompta $(G=0.463, p=0.849)$. The prevalence of monogeneans in M. lippincottianus was similar to C. incompta $(G=1.876, p=0.229)$, and lower than in $A$. bimaculatus $(\mathrm{G}=33.565, \mathrm{p}=<0.001)$. The prevalence of monogeneans in A. bimaculatus was higher than in $C$. incompta $(G=25.499, p=<0.001)$.

The infection by monogeneans in M. lippincottianus (ID $=2.290, d=6.8, \mathrm{D}=0.859$ ), Plagioscion squamosissimus (ID $=5.930, d=14.3, \mathrm{D}=0.763), A$. bimaculatus $(\mathrm{ID}=3.450, d=10.4, \mathrm{D}=0.843)$ and . incompta $(\mathrm{ID}=4.550, d=18.3$, $\mathrm{D}=0.855$ ) had a highly aggregated dispersion pattern.

There was no correlation between the abundance of monogeneans and the length $(r s=-0.203, p=0.152$ ) and weight ( $r s=-0.187, p=0.188$ ) of $P$. squamosissimus. A weak positive correlation between the abundance of monogeneans and the length $(r s=0.293, p=0.0006)$ was found, but there was no correlation with the weight $(r s=0.099, p=0.257$ ) of $C$. incompta. There was a correlation between the abundance of monogeneans and the length ( $r s=0.187, p=0.078$ ) of $M$. lippincottianus, but a weak positive correlation between the abundance of monogeneans and the weight ( $r s=0.204, p=0.05$ ) was observed. For $A$. bimaculatus, there was a correlation between the abundance of monogeneans and the length $(r s=-0.033, p=0.781)$ and weight $(r s=0.041, p=0.439)$ of hosts.

\section{Discussion}

Monogeneans are parasites that are part of the biodiversity of ecosystems and serve as indicators of environmental quality, since they are generally present in greater abundance in environments with poor quality (Dogiel, 1961; Lizama et al., 2008; Takemoto et al., 2013; Ferreira-Sobrinho \& Tavares-Dias, 2016; Lapera et al., 2017; Oliveira et al., 2017; Tavares-Dias et al., 2017). In M. lippincottianus, P. squamosissimus, C. incompta and A. bimaculatus, there was an aggregated dispersion for monogeneans, a pattern also reported for these parasites in other wild fish populations (Lizama et al., 2008; Hoshino \& Tavares-Dias, 2014; Oliveira et al., 2017; Gallegos-Navarro et al., 2018), due to genetic heterogeneity, exposure and susceptibility of the host population and local environmental factors (Oliveira \& Tavares-Dias, 2016; Tavares-Dias et al., 2017; Oliveira et al., 2017; Gallegos-Navarro et al., 2018).

In fish populations, sometimes the parasite abundance is correlated with body size of the host population, but this correlation may also be weak or non-existent due to several factors, for example, small variation in host size, small sampling, etc. (Lizama et al., 2008; Hoshino \& Tavares-Dias, 2014; Tavares-Dias et al., 2014, 2017; Neves et al., 2016; Oliveira \& Tavares-Dias, 2016; Lapera et al., 2017; Gallegos-Navarro et al., 2018). In M. lippincottianus from the Matapi River, the abundance of $A$. jegui had a weak positive correlation with body weight of this host. The abundance of Urocleidoides spp. also showed a weak positive correlation with the length of $C$. incompta. Similar finding was reported by Neves et al. (2016) for this same host from the Igarapé Fortaleza basin, in State of Amapá. Therefore, weight or length had little influence on the monogenean community of these two hosts.

In this study, Plagioscion auratus was not infected by any monogenean species, but $P$. squamosissimus was infected by $D$. piscinarius, E. succedanus and A. goeldiensis, and $P$. surinamensis was infected only by $E$. succedanus. However, Cohen et al. (2013) listed other species of monogeneans also infecting P. squamosissimus in Brazil: 


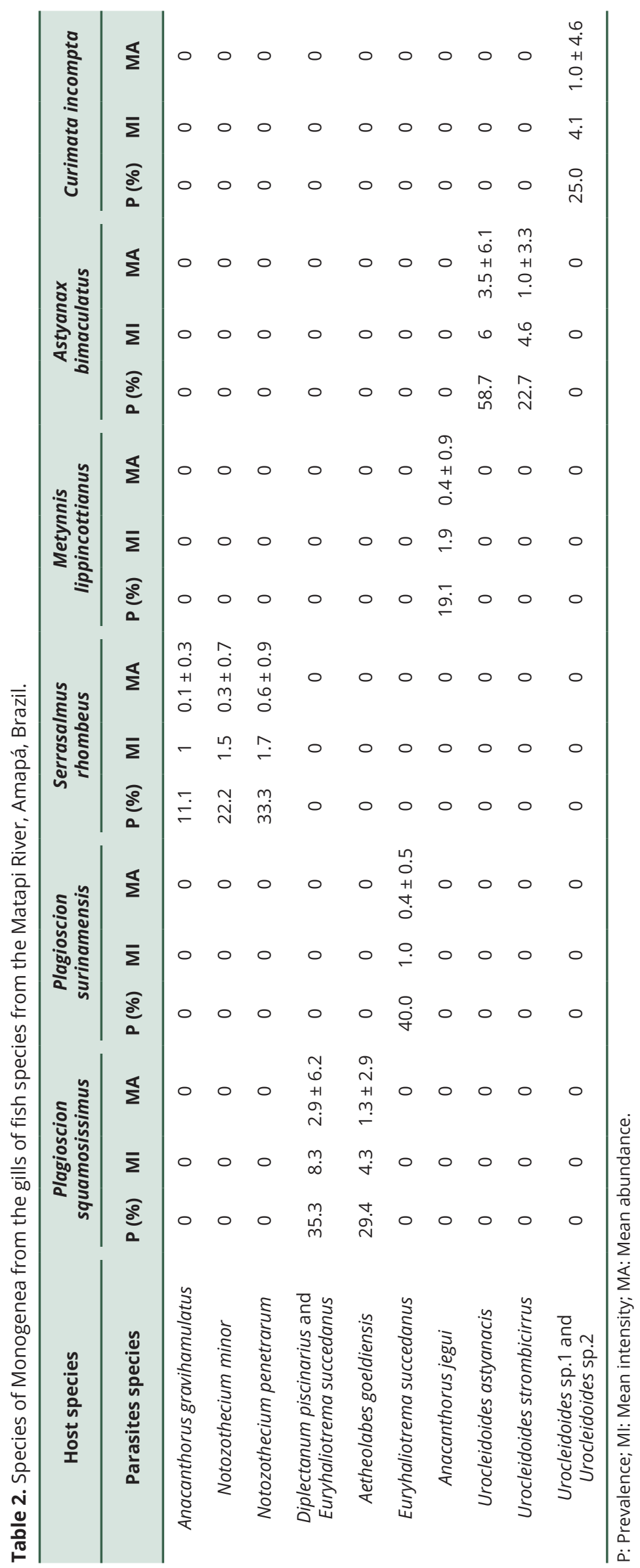


Diplectanum decorrum Kritsky \& Thatcher, 1984; Diplectanum gymnopeus, Kritsky \& Thatcher, 1984; Diplectanum pescadae, Kritsky \& Thatcher, 1984; Euryhaliotrema chaoi, Kritsky and Boeger, 2002; Euryhaliotrema potamocetes, Kritsky \& Boeger, 2002 and Euryhaliotrema thatcheri, Kritsky \& Boeger, 2002. The infection levels of monogeneans in $P$. squamosissimus and $P$. surinamensis were similar, since they are congeneric species of hosts inhabiting the same environment. However, in $P$. squamosissimus from the Tietê River, where it was introduced, there was infection only by $D$. piscinarius (Lapera et al., 2017) and the parasitism levels were higher than in $P$. squamosissimus and $P$. surinamensis of the current study. Lapera et al. (2017) showed that infections by $D$. piscinarius cause lesions in the gills of $P$. squamosissimus, because this monogenean species can be potentially harmful to hosts.

In M. lippincottianus, we found only A. jegui, and infection levels were lower than the reported by Hoshino \& Tavares-Dias (2014), for this same host in the Igarapé Fortaleza basin. Serrasalmus rhombeus was infected by A. gravihamulatus, N. minor and N. penetrarum. Cohen et al. (2013) listed other 22 species of monogeneans infecting S. rhombeus in Brazil, of which 4 are species of Amphitthecium, 7 Anacanthorus, 3 Enallothecium, 3 Mymarothecium, 4 Notothecium and 1 Notozothecium. However, this is the first record of N. penetrarum for S. rhombeus, because this parasite was originally described in Pygocentrus nattereri Kner, 1960 from the Guaporé River, State of Rondônia, northern Brazil (Boeger \& Kritsky, 1988). In addition, the infection levels of monogeneans in S. rhombeus were lower than reported for P. nattereri from the Solimões River, State of Amazonas (Vital et al., 2011).

Astyanax bimaculatus from the Matapi River was infected by $U$. astyanacis and $U$. trombicirrus, but $U$. astyanacis presented higher infection levels. However, infection levels by these monogeneans were higher than those observed for Urocleidoides sp., Amphitecium sp. and Notozothecium spp. in Astyanax altiparanae Garutti \& Britski, 2000 from the Upper Paraná River, State of Paraná, Brazil (Lizama et al., 2008). In the present study, Curimata incompta was infected by Urocleidoides spp., a similar finding reported also for C. incompta (Neves et al., 2016) and for Curimata cyprinoides Linnaeus, 1766 (Tavares-Dias et al., 2013) both hosts from the Igarapé Fortaleza basin. Despite these results, species of monogeneans that parasitize fish of the genus Curimata are still unknown (Cohen et al., 2013). In addition, infection levels by Urocleidoides spp. in C. incompta were lower than the reported for C. cyprinoides (Tavares-Dias et al., 2013) and for C. incompta from the Igarapé Fortaleza basin, an environment eutrophicated due to the urbanization of two municipalities (Tavares-Dias et al., 2013; Neves et al., 2016).

\section{Conclusions}

We found a diversity of monogenean species with distinct infection patterns in the studied fish species that may has been influenced by the host species and sampling. This is the first study for these fish species from the Matapi River, recording for the first time $E$. succedanus for $P$. surinamensis and Notozothecium penetrarum for S. rhombeus. The present study established fauna and infection data for monogeans in different fish species from Matapi River basin, an ecosystem that is subject to an increase in environmental changes due to agriculture, extensive breeding of buffalo in the várzea forests, urbanization and industrialization. Thus, these data will be used for comparisons in future studies regarding environmental impacts from anthropogenic actions in this basin.

\section{Acknowledgements}

The authors thank to the Coordenação de Aperfeiçoamento de Pessoal de Nível Superior (CAPES) by the doctoral grant was granted to the first author and to the Conselho Nacional de Desenvolvimento Científico e Tecnológico (CNPq) for the productivity research grant awarded to Dr. M. Tavares-Dias (\# 303013/2015-0).

\section{References}

Boeger WA, Kritsky DC. Neotropical Monogenea. 12. Dactylogyridae from Serrasalmus nattereri (Cypriniformes, Serrasalmidae) and aspects of their morphologic variation and distribution in the Brazilian Amazon. Proc Helminthol Soc Wash 1988; 55(2): 188-213.

Bush AO, Lafferty KD, Lotz JM, Shostak AW. Parasitology meets ecology on its own terms: margolis et al. revisited. J Parasitol 1997; 83(4): 575-583. http://dx.doi.org/10.2307/3284227. PMid:9267395.

Cohen SC, Justo MCN, Kohn A. South American Monogenoidea parasites of fishes, amphibians and reptiles. Rio de Janeiro: Oficina de Livros; 2013.

Dogiel VA. Ecology of the parasites of freshwater fishes. In: Dogel VA, Petrushevski GK, Polyanski Yl, editors. Parasitology of fishes. Leningrad: University Press; 1961. p. 1-47. 
Eiras JC, Takemoto RM, Pavanelli GC. Métodos de estudo e técnicas laboratoriais em parasitologia de peixes. 2nd ed. Maringá: EDUEM; 2006.

Ferreira-Sobrinho A, Tavares-Dias M. A study on monogenean parasites from the gills of some cichlids (Pisces: Cichlidae) from the Brazilian Amazon. Rev Mex Biodivers 2016; 87(3): 1002-1009. http://dx.doi.org/10.1016/j.rmb.2016.06.010.

Gallegos-Navarro Y, Violante-González J, Monks S, García-lbáñez S, Rojas-Herrera AA, Pulido-Flores G, et al. Factors linked to temporal and spatial variation in the metazoan parasite communities of green jack Caranx caballus (Günther 1868) (Pisces: Carangidae) from the Pacific coast of Mexico. J Nat Hist 2018; 52(39-40): 2573-2590. http://dx.doi.org/10.1080/00222933.2018. 1546914.

Hoshino MDFG, Tavares-Dias M. Ecology of parasites of Metynnis lippincottianus (Characiformes: Serrasalmidae) from the eastern Amazon region, Macapá, State of Amapá, Brazil. Acta Sci Biol Sci 2014; 36(2): 249-255. http://dx.doi.org/10.4025/actascibiolsci. v36i2.19876.

Lapera IM, Silva AC, Canônico BM, Perezin GF, Tebaldi JH, Pala G, et al. Metazoan parasites of Plagioscion squamosissimus, an invasive species in the Tietê River, São Paulo, Brazil. Braz J Vet Parasitol 2017; 26(2): 143-151.

Leal WMM, Freitas CEC, Siqueira-Souza FK. Diversidade de peixes em lagos manejados em área de várzea Amazônica brasileira. Scientia Amaz 2018; 7(1): 1-10.

Lizama MLAP, Takemoto RM, Pavanelli GC. Ecological aspects of metazoan parasites of Astyanax altiparanae Garutti \& Britski, 2000 (Characidae) of the upper Paraná River floodplain, Brazil. Bol Inst Pesca 2008; 34(4): 527-533.

Ludwig JA, Reynolds JF. Statistical ecology: a primer on methods and computing. New York: Wiley-Interscience Pub; 1988.

Neves LR, Braga ECR, Tavares-Dias M. Diversity of parasites in Curimata incompta (Curimatidae), a host from Amazon River system in Brazil. J Parasit Dis 2016; 40(4): 1296-1300. http://dx.doi.org/10.1007/s12639-015-0674-0. PMid:27876934.

Oliveira MSB, Gonçalves RA, Ferreira DO, Pinheiro DA, Neves LR, Dias MKR, et al. Metazoan parasite communities of wild Leporinus friderici (Characiformes: Anostomidae) from Amazon River system in Brazil. Stud Neotrop Fauna Environ 2017; 52(2): 146-156. http://dx.doi.org/10.1080/01650521.2017.1312776.

Oliveira MSB, Tavares-Dias M. Communities of parasites metazoans in Piaractus brachypomus (Pisces, Serrasalmidae) in the lower Amazon River (Brazil). Rev Bras Parasitol Vet 2016; 25(2): 151-157. http://dx.doi.org/10.1590/S1984-29612016022. PMid:27334815.

Rózsa L, Reiczigel J, Majoros G. Quantifying parasites in samples of hosts. J Parasitol 2000; 86(2): 228-232. http://dx.doi. org/10.1645/0022-3395(2000)086[0228:QPISOH]2.0.CO;2. PMid:10780537.

Santos VF, Costa WJP, Silva MS, Silveira OFM, Torres AM, Silva AQ, et al. Geologia. In: Santos VF, Figueira ZR, editors. Diagnóstico sócio-ambiental participativo do setor costeiro estuarino do estado do Amapá. Macapá: MMA/GEA/IEPA; 2004. p. 11-34.

Silva LMA, Lima JF, Tavares-Dias M. Ictiofauna como indicadora da qualidade ambiental do Rio Matapi, afluente do Rio Amazonas no estado do Amapá (Brasil). Macapá: Embrapa Amapá; 2016. (Boletim de Pesquisa e Desenvolvimento; vol. 92).

Sousa BO, Oliveira MSB, Tavares-Dias M. Community structure of metazoan parasites in Hemibrycon surinamensis (Characidae) from the Matapi River in the State of Amapá, Brazil. An Acad Bras Cienc 2019; 91(2): e20180393. http://dx.doi.org/10.1590/00013765201920180393 . PMid:31269104.

Takemoto RM, Luque JL, Bellay S, Longhini CE, Graça RJ. Monogenea. In: Pavanelli GC, Takemoto RM, Eiras JC, editors. Parasitologia: peixes de água doce no Brasil. Maringá: Eduem; 2013. p. 273-299.

Tavares-Dias M, Neves LR, Pinheiro DA, Oliveira MSB, Marinho RGB. Parasites in Curimata cyprinoides (Characiformes: Curimatidae) from eastern Amazon, Brazil. Acta Sci Biol Sci 2013; 35(4): 595-601. http://dx.doi.org/10.4025/actascibiolsci.v35i4.19649.

Tavares-Dias M, Oliveira MSB, Gonçalves RA, Neves LR. Parasitic diversity of a wild Satanoperca jurupari population, an ornamental cichlid in the Brazilian Amazon. Acta Amazon 2017; 47(2): 155-162. http://dx.doi.org/10.1590/1809-4392201602514.

Tavares-Dias M, Oliveira MSB, Gonçalves RA, Silva LMA. Ecology and seasonal variation of parasites in wild Aequidens tetramerus, a Cichlidae from the Amazon. Acta Parasito/ 2014; 59(1): 158-164. http://dx.doi.org/10.2478/s11686-014-0225-3. PMid:24570063.

Vital JF, Varella AMB, Porto DB, Malta JCO. Sazonalidade da fauna de metazoários de Pygocentrus nattereri (Kner, 1858) no lago Piranha (Amazonas, Brasil) e a avaliação de seu potencial como indicadora da saúde do ambiente. Biota Neotrop 2011; 11(1): 199-204. http://dx.doi.org/10.1590/S1676-06032011000100021.

Whittington ID, Chisholm LA. Diseases caused by Monogenea. In: Eiras JC, Segner H, Wahli T, Kapoor BG, editors. Fishes diseases. New Hampshire: Science Publishers; 2008. p. 683-816.

Zar JH. Biostatistical analysis. 5th ed. Englewood Cliffs: Prentice Hall; 2010. 